\title{
Bioactive Compounds in Brassicaceae Vegetables with a Role in the Prevention of Chronic Diseases
}

\author{
Assunta Raiola ${ }^{1}$, Angela Errico ${ }^{1}$, Ganna Petruk ${ }^{2}$, Daria Maria Monti ${ }^{2}$, Amalia Barone ${ }^{1, *}$ and \\ Maria Manuela Rigano ${ }^{1, *}$ \\ 1 Department of Agricultural Sciences, University of Naples Federico II, Via Università 100, \\ 80055 Naples, Italy; assuntaraiola@hotmail.com (A.R.); angela.errico@unina.it (A.E.) \\ 2 Department of Chemical Sciences, University of Naples Federico II, Complesso Universitario di Monte \\ Sant'Angelo, 80055 Naples, Italy; ganna.petruk@unina.it (G.P.); mdmonti@unina.it (D.M.M.) \\ * Correspondence: ambarone@unina.it (A.B.); mrigano@unina.it (M.M.R.); Tel.: +39-081-2539486 (A.B.); \\ +39-081-2532125 (M.M.R.); Fax: +39-081-2531718 (A.B. \& M.M.R.)
}

Received: 11 December 2017; Accepted: 20 December 2017; Published: 23 December 2017

\begin{abstract}
The beneficial role of the Mediterranean diet in the prevention of chronic diseases, including cardiovascular diseases, diabetes, and obesity, is well-recognized. In this context, Brassicaceae are considered important vegetables due to several evidences of their health promoting effects that are associated to bioactive compounds present in the edible parts of the plants. In this review, the mechanisms of action and the factors regulating the levels of the bioactive compounds in Brassicaceae have been discussed. In addition, the impact of industrial and domestic processing on the amount of these compounds have been considered, in order to identify the best conditions that are able to preserve the functional properties of the Brassicaceae products before consumption. Finally, the main strategies used to increase the content of health-promoting metabolites in Brassica plants through biofortification have been analyzed.
\end{abstract}

Keywords: chronic diseases; glucosinolates; phenolic compounds; ascorbic acid; carotenoids; biofortification

\section{Introduction}

The Brassicaceae family consists of about 3500 species, and includes 350 genera, such as Brassica, Camelina, Crambe, Sinapis, and Thlaspi. In particular, the genus Brassica includes some species of worldwide economic importance, such as Brassica oleracea, Brassica rapa L., and Brassica napus [1].

Several species, which belong to the Brassicaceae family, represent an important part of the human diet worldwide; indeed, when regularly consumed, they have been found to exert health-promoting effects, such as a reduction in the risk of chronic diseases, particularly cardio-vascular diseases and several types of cancer [2,3]. These effects have been linked to the presence in these plants of phenolics, glucosinolates, carotenoids, tocopherols, and ascorbic acid, well-known antioxidants [4]. In particular, broccoli, white cabbage, and cauliflower are rich in glucosinolates, and, more in detail, in glucoraphanin, a molecule that is transformed by myrosinase into sulforaphane, that is a compound endowed with anticarcinogenic properties [5].

In this review, we describe how a reduced risk of chronic diseases development may be a consequence of Brassicaceae consumption. Furthermore, we analyze the specific mechanisms of action of the most important bioactive compounds that are present in the genus Brassica. Finally, we debate on the biotechnological approaches that can be used to enrich the content of antioxidant compounds in the edible parts of Brassica plants. 
Brassicaceae are usually consumed after cooking; therefore, it is necessary to use appropriate agronomic techniques combined with proper processing techniques to manage and/or improve the general quality of the final Brassica product used for consumption [6]. Therefore, here, the impact of different practices used both pre- and post-harvest and their effects on the amount of bioactive compounds in Brassicaceae products are also discussed.

\section{Bioactive Compounds in Brassicaceae and Their Effects on Chronic Diseases}

The Mediterranean diet, which is characterized by a high consumption of plant-based foods, has been associated with a lower risk of cardiovascular diseases and mortality in different epidemiological studies. In the last few years, several studies, both in vitro and in vivo, have focused on the effects of Brassicaceae on chronic diseases and on the bioactive compounds of these plants that may be responsible for the observed effects [7,8] (Figure 1). It has been discussed that the known healthy effects of Brassicaceae may be related to the presence of several bioactive compounds in the edible parts, such as ascorbic acid (AsA), phenolics, carotenoids, and glucosinolates, as summarized in Table $1[9,10]$.

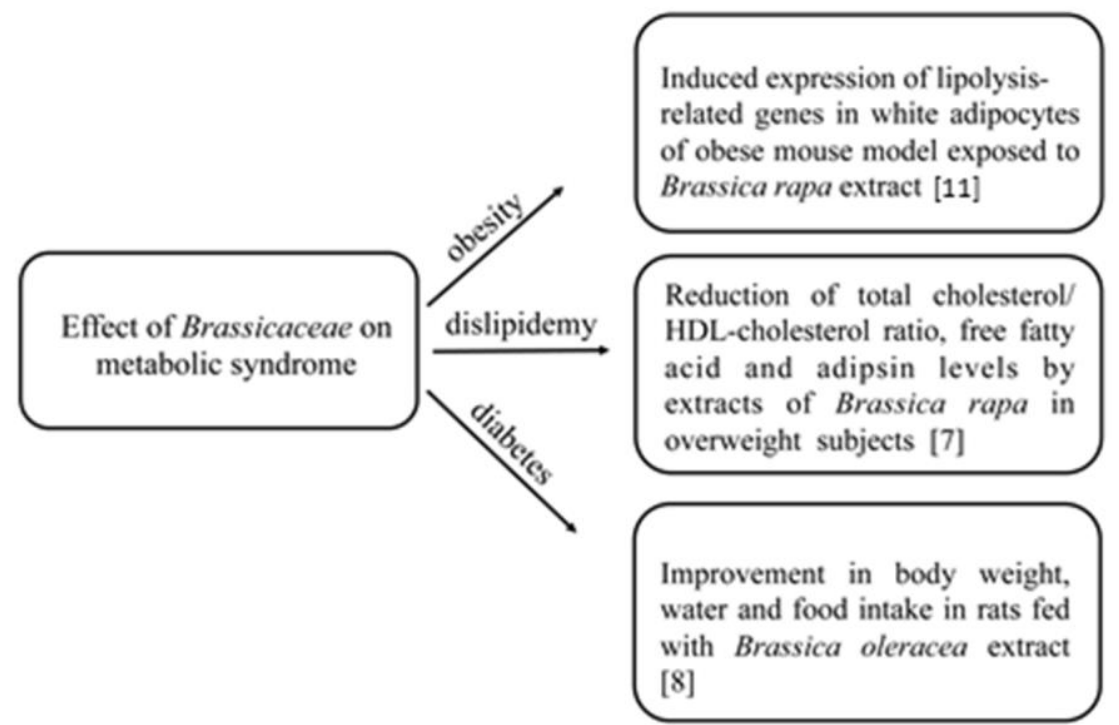

Figure 1. Main effects of Brassicaceae consumption on metabolic syndromes.

Table 1. Mechanisms of action of bioactive compounds in Brassicaceae.

\begin{tabular}{clc}
\hline Compound & \multicolumn{1}{c}{ Mechanism } & Reference \\
\hline \multirow{3}{*}{ Ascorbic acid } & ROS reduction and neutralization & {$[12]$} \\
\cline { 2 - 2 } & Protection against LDL oxidation & \multirow{2}{*}[13]{} \\
\cline { 2 - 2 } & Prevention of oxLDL-induced overexpression of Vascular Endothelial Growth Factor & \\
\hline \multirow{2}{*}{ Phenolics } & ROS neutralization & \multirow{2}{*}[14]{} \\
\cline { 2 - 3 } & Chelation of redox-active metal ions and inhibition of LDL-cholesterol oxidation & \\
\hline Carotenoids & Radical scavengers and quenches of singlet oxygen & {$[15]$} \\
\hline \multirow{2}{*}{ Glucosinolates } & Inhibition of the invasive potential of human cancer cell line in vitro & {$[16]$} \\
\cline { 2 - 3 } & Regulation of the phase I and/or phase II detoxification enzymes activity & {$[17]$} \\
\hline
\end{tabular}

AsA and dehydroascorbic acid are known to reduce and neutralize reactive oxygen species (ROS) [12]. Moreover, AsA is able to protect the myocardium when associated to ferulic acid [18], and, in association with vitamin E, it can prevent oxLDL-induced overexpression of vascular endothelial growth factor (VEGF), responsible for atherosclerotic plaque formation [13]. Cultivated broccoli normally contain high amount of Vitamin C, ranging between 70 and $120 \mathrm{mg} / 100 \mathrm{~g}$ fresh weight (FW) [19]. 
However, the content of AsA in Brassica depends on the investigated cultivar, sulfur fertilization, and on post-harvest handling conditions [20-23]. For example, the microorganism Trichoderma harzianum, a known biocontrol agent, and its metabolites (harzianum acid and 6-pentyl-a-pyrone) were able to increase AsA content when used on plants of the ecotype "Friariello" from the Campania region [14].

Phenolic compounds have been studied for their ability to chelate redox-active metal ions, to inhibit LDL cholesterol oxidation, and to neutralize other processes involving ROS, since they are efficient free radical scavengers [14]. Moreover, dietary polyphenols may inhibit the growth of adipose tissue by modulating adipocyte metabolism [24]. It is reported that polyphenols are able to enhance glucose uptake in adipocytes and muscle cells by GLUT4, a glucose transporter that exerts its action through the AMP-activated protein kinase pathway [25]. It has also been demonstrated that flavonoids can normalize blood glucose levels and promote $\beta$-cell regeneration in islets of alloxan-treated rats [26], while epicatechin and quercetin can improve insulin production in isolated rat islets [27]. Turnip leaf (Brassica rapa) extracts, which are rich in flavonoids and tannins, showed an anti-hyperglycemic activity in alloxan-induced diabetic rats [28]. In general, different varieties of broccoli may have different total phenolics content, ranging from 5 up to $8 \mathrm{mg} / \mathrm{g}$ dry weight (DW) $[19,21]$. The amount of total phenolics in Brassica may be further increased by using specific agronomic techniques, such as sulphur fertilization and/or light-treatment [4,29].

Carotenoids are pigments precursors of vitamin A (i.e., $\beta$-carotene, $\gamma$-carotene, and $\beta$-cryptoxanthin), which are characterized by the presence of conjugated double bonds responsible for the radical scavengers and quenchers of singlet oxygen. It has been reported that carotenoids level in Brussels sprouts is $6 \mathrm{mg} / 100 \mathrm{~g} \mathrm{FW}$, about $2 \mathrm{mg} / 100 \mathrm{~g}$ FW in broccoli, $0.5 \mathrm{mg} / 100 \mathrm{~g}$ FW in red cabbage, and $0.26 \mathrm{mg} / 100 \mathrm{~g}$ FW in white cabbage [15]. Higher $\beta$-carotene serum levels have been linked to lower rates of cancer and cardiovascular diseases, as well as to decreased risks of myocardial infarction. Moreover, serum $\beta$-cryptoxanthin and $\beta$-carotene amount have been negatively correlated with metabolic syndrome factors [30].

Glucosinolates represent a group of phytochemicals found in 15 botanical families of the order of Capparales and are very abundant in Brassicaceae [31]. A very different profile of glucosinolates may be found in different broccoli extracts [32]. In a recent paper, the most abundant glucosinolates found in different broccoli samples were glucobrassicin and neoglucobrassicin, followed by glucoraphanin. Interestingly, glucoraphanin, which is one of the most representative glucosinolates in broccoli, was completely absent in the ecotype "Friariello" from the Campania region [31]. Also, the content of glucosinolates may be deeply different in different broccoli varieties. For example, analyses conducted on a collection of 113 varieties of turnip greens (Brassica rapa L.), cultivated in two different sites in Spain, showed glucosinolates contents ranging from 12 to $70 \mu \mathrm{mol} / \mathrm{g}$ DW at one site, and from 7 to $60 \mu \mathrm{mol} / \mathrm{g}$ DW at the other site [32].

Intact glucosinolates are biologically inactive, whereas after the disruption of plant cells, they are hydrolysed by a $\beta$-thioglucosidase enzyme called myrosinase. Among the breakdown products, the isothiocyanates are associated to important protecting effects [33]. In addition to the prevention of chronic disease, it is largely reported a strong correlation between the consumption of cruciferous vegetables and the decreased risk for different types of cancer. Indeed, it has been demonstrated that extracts of broccoli and watercress inhibit the invasive potential of human breast cancer cell lines in vitro [31]. This effect may be explained by the ability of glucosinolates-hydrolysis products to regulate the phase I and/or phase II detoxification enzymes activity [17]. Therefore, isothiocyanates could be considered as a new class of invasion inhibitors.

In the last few years, several studies both in vitro and in vivo have been carried out on the effects of Brassicaceae on chronic diseases [7,8]. By using an obese mouse model, a study demonstrated that the exposure of mice to ethanolic extracts from Brassica rapa resulted in the expression of lipolysis-related genes in white adipocytes, in the activation of cyclic AMP-dependent protein kinase, and in the induction of extracellular signal-regulated kinase, suggesting that Brassicaceae extracts may be used as safe and effective anti-obesity agents [11]. 
In another in vivo study, extracts from Brassica rapa were used for 10 weeks as a part of the diet of overweight human subjects. At the end of the experiment, a significant increase in the high-density lipoprotein cholesterol (HLDL-cholesterol) concentration and a significant reduction in the total cholesterol/HDL-cholesterol ratio, free fatty acid, and adipsin levels were measured [7]. Also, Shah et al. [8] used extracts from Brassica oleracea leaves to analyze its anti-diabetic effect on rats. After having induced diabetes in rats, animals were fed for 28 days with Brassica oleracea, and then, a significant improvement in body weight and in water and food intake was observed [8]. In rats fed with an atherogenic diet, the assumption of red cabbage, highly rich in anthocyanins, was able to increase faecal lipid excretion, with a reduced risk of tissue lipids, hepatic, and cardiac peroxidation [34]. Moreover, it has been demonstrated that Brassica oleracea kale leaves extracts can inhibit lipid peroxidation in LDL isolated from human volunteers [35], while extracts from Brassica rapa L. oleifera can suppress postprandial hypertriglyceridemia in mice due to the presence of gluconapin and sinigrin [36]. Finally, it has been proved that the combination of Brassica olearaceae L. and hydrosoluble chitosan was able to reduce triglycerides, serum total cholesterol, and LDL-cholesterol in rats, and that this combination was much more effective than that obtained by combining chitosan and Aloe vera extract [37,38]. A further protective effect of Brassicaceae is represented by the inhibition of mechanisms regulating the development of cancer. Indeed, a 2-pyrrolidinone rich extract from Brassica oleracea showed in vitro cytotoxicity on HeLa and PC-3 human cancer cell lines, and it also exhibited antioxidant activity in a cell-free system [39]. Adverse effects of compounds that are present in Brassicaceae towards metabolic syndromes are also possible. For example, the potential additive and synergistic effects of flavonoids from Brassicaceae with other molecules could interfere with the bioavailability of specific drugs with a narrow therapeutic index [9].

\section{Biofortification to Optimize the Content of Bioactive Compounds in Brassicaceae}

Biofortification is a sustainable approach that is based on the fortification of crops through the utilization of nutrient-rich fertilizers, breeding or plant engineering strategies in order to produce and/or accumulate nutritionally important molecules [40]. Among these techniques, conventional breeding could show some disadvantages since it requires long time to introduce traits of interest into local varieties, whereas, through genetic engineering, novel genes can be directly introduced into the genome of transgenic plants. Furthermore, genetic engineering allows for combining several traits in the same plants and nutritional traits can be targeted to specific plant organs [41,42].

Brassicaceae represent an ideal system for studying the genetic factors that are controlling the accumulation of bioactive compounds. Indeed, up to date, in the Brassicaceae family, the genomes of ten species have been partially or completely sequenced and the conserved sequence homology to Arabidopsis thaliana allows for the development of specific genomic resources [43]. Several molecular markers have been introduced for genetic studies in Brassica plants, such as restriction fragment length polymorphisms (RFLP), amplified fragment length polymorphisms (AFLP), sequence-related amplified polymorphisms (SRAP), random amplified polymorphic DNA (RAPD), and simple sequence repeats (SSR) [44]. Molecular maps and mapping populations have also been developed by using several varietal groups and subspecies as parents. Quantitative trait loci (QTLs) controlling the accumulation of bioactive compounds, including carotenoids and glucosinolates, have also been identified in Brassicaceae [44]. Several studies have been conducted on the structural and regulatory genes involved in the biosynthesis of bioactive compounds of broccoli. For example, a recent study [45] reported that the protein phosphatase $2 \mathrm{~A}$ regulatory subunit $\mathrm{B}^{\prime} \gamma\left(\mathrm{PP}^{\mathrm{A}} \mathrm{A}-\mathrm{B}^{\prime} \gamma\right)$ physically interacts with indole glucosinolate methyltransferases. In this way, both the methoxylation of indole glucosinolates and the synthesis of 4-methoxy-indol-3-yl-methyl glucosinolate in Arabidopsis thaliana leaves are controlled. These evidences provide a new perspective for metabolic engineering of glucosinolate metabolism in cruciferous plants.

Obtaining transgenic plants could be a valid alternative strategy to improve the content of specific molecules by either inactivating or overexpressing genes, or cloning the regulatory factors [46]. In this 
regard, many studies have been conducted in order to increase the content of glucosinolates. In one study, transgenic Chinese cabbage (Brassica rapa) was obtained by overexpressing the Arabidopsis genes MAM1, CYP79F1, and CYP83A1. Only in the MAM1 transgenic line, increased levels of aliphatic glucosinolates, gluconapin, and glucobrassicanapin were observed [47]. Overexpression of three paralogous BrMYB28 genes in transgenic Chinese cabbage increased the total content of glucosinolates in homozygous $\mathrm{T}_{1}$ and $\mathrm{T}_{2}$ generation plants [48]. Finally, overexpressing a rolB gene in Arabidopsis thaliana calli, a 3-folds increase in the levels of indol-3-ylmethyl glucosinolate and 4-methoxy indol-3-ylmethyl glucosinolate was found. This effect was probably due to the ability of the rolB gene to induce the expression of the transcription factors MYB34, MYB51 and MYB122 [49].

A high level of vitamin E was also achieved in transgenic Brassica napus plant seeds by overexpressing Arabidopsis genes encoding hydroxyl phenyl pyruvate dioxygenases, alone or in combination with genes encoding chimeric homogentisate phytyl transferase and tocopherol cyclase [50]. To enhance the amount of carotenoids in Brassica napus plants, seven key enzyme genes that are involved in ketocarotenoid synthesis, isolated from the soil bacterium Pantoea ananatis, and from the marine bacteria Brevundimonas and Paracoccus strain, were expressed in transgenic plants [51]. In another paper, the Arabidopsis regulatory gene Production of Anthocyanin Pigment 1 (AtPAP1) was expressed in Brassica napus, thus obtaining a significant increase in the levels of the phenolic compounds cyanidin, pelargonidin, and quercetin [52].

A further possible strategy for the production of healthy compounds, such as glucosinolates and phenolic compounds in turnip, could be represented by infection with Agrobacterium rhizogenes to obtain transgenic hairy root cultures [53]. For example, metabolic engineering of indolic glucosinolates in Chinese cabbage hairy roots was obtained by the overexpression of the Arabidopsis genes CYP79B2, CYP79B3, and CYP83B1 [54,55].

Finally, another approach to increase the content of bioactive compounds has been recently considered and is represented by plant cell cultures in vitro. This method offers several advantages when compared with whole plants. For example, using sterilized containers, pathogens are avoided, as well as an undesirable distribution of pollen and cross-fertilization. In addition, cultured plant cells need simple nutrients to grow. Moreover, the purification of the bioactive compound is facilitated since complex plant fibers are not present with the consequent reduction of production costs [56]. These factors can allow for further optimizing the culture conditions, and, thus, increase the bioproduction of glucosinolates [57].

\section{Effect of Food Processing Techniques on Bioactive Compounds Content}

It has been demonstrated that food processing may significantly affect the concentration and biological activity of the compounds that are present in vegetables. This is an important point, as the majority of vegetables are consumed after thermal treatment, which can have several effects, some of which are reported in Table 2.

During cooking, qualitative changes, antioxidant degradation, and release into surrounding water may affect the antioxidant activity of vegetables. As for Brassicaceae, it has been reported that boiling determined losses of 97,74 , and $87 \%$ in flavonoids, sinapic acid derivatives, and caffeoylquinic acid derivatives, respectively [58]. Losses were reduced to $20-30 \%$ by steaming cooking, revealing that this is the optimal method to safeguard secondary metabolites in Brassica crops [59].

After boiling and steaming, a loss in AsA content of $34 \%$ and $22 \%$ was reported for broccoli, while microwaving and pressure-cooking, caused more than 90\% retention [60] and conversion of AsA to dehydroascorbic acid (DHAA) was observed after the thermal treatments for $15 \mathrm{~min}$ of crushed broccoli at $30^{\circ} \mathrm{C}$ up to $60^{\circ} \mathrm{C}$ [61]. Thermal treatment, such as steaming, is associated to the inactivation of myrosinases enzymes, resulting in low loss of glucosinolates. When compared to steaming, a higher reduction of glucosinolates was observed during boiling and microwave cooking since glucosinolates leach into the boiling water due to their highwater solubility, while around $90 \%$ of glucosinolates is lost in cooking water [62]. Glucosinolates were reduced by $55 \%, 54 \%, 60 \%$, and $41 \%$, in stir-fried, 
stir-fried/boiled, microwaved, and boiled broccoli, respectively [63]. The majority of domestic cooking causes myrosinase denaturation, while glucosinolates remain intact. Blanching cruciferous vegetables prior to freezing may denature myrosinase, thus whole glucosinolates are consumed [64]. Also, storage at a low temperature has an effect on the antioxidant activity, as chilling at $6{ }^{\circ} \mathrm{C}$ for 35 days determined sulforaphane loss of $29 \%$, while storage at $-18^{\circ} \mathrm{C}$ for 60 days resulted in loss mainly attributed to the blanching step [61].

Modified atmosphere packaging (MAP) also may exert an effect on the content of glucosinolates of broccoli florets. MAP treatment reduced the decreasing levels rates of individual, indole glucosinolates and total aliphatic in broccoli florets when compared to those in the control, during 23 days of storage at $4{ }^{\circ} \mathrm{C}$ or five days of storage at $20^{\circ} \mathrm{C}$ [65].

On the other side, cooking of vegetables can enhance the bioavailability of some bioactive molecules. A study investigated the extractability of carotenoids, flavonoids, phenolic compounds, and chlorophylls in cooked broccoli and cauliflower, and found that cooking can, in some cases, improve the extractability of bioactive compounds in vegetables [66].

Table 2. Summary of impact of domestic and industrial processing on the nutritional quality of Brassicaceae.

\begin{tabular}{|c|c|c|}
\hline Treatment & Effect on Nutritional Quality & Reference \\
\hline \multirow{2}{*}{ High pressure boiling } & Degradation of hydroxycinnamic acids and flavonoids & [60] \\
\hline & Glucosinolates hydrolysis causing the formation of isothiocyanates & [62] \\
\hline \multirow{2}{*}{ Steaming cooking } & Reduction of phenolic degradation & [59] \\
\hline & Inactivation of myrosinase and low loss of glucosinolates & {$[62]$} \\
\hline Microwaving- pressure cooking & Low loss of AsA and carotenoids & {$[60]$} \\
\hline MAP treatment & Good preservation of glucosinolates & [65] \\
\hline
\end{tabular}

\section{Conclusions}

A variety of vegetables belong to the family of Brassicaceae that are considered among the most important weeds in the world. These vegetables provide dietary fiber, vitamins, anti-cancer glucosinolates, dietary flavonols, and anthocyanins. The content of these compounds in Brassica food is affected by genetic background, climatic conditions, crop management strategies, time, and other conditions of storage, characterizing the time from harvest to initial processing in the industry or retailer, as well as the methods that are adopted for cooking and consumption at home [67].

Bioavailability of antioxidants and glucosinolates are also related to the association with other food constituents. The bioavailability of glucosinolates and their breakdown products depends also by the inactivation or not of myrosinases. Further investigations are desirable in order to deeply analyze the impact of each agronomic parameter on the accumulation and synthesis of these compounds in the different crops belonging to Brassicaceae. In addition, further genetic studies are needed to identify the genetic determinants that control the accumulation of bioactive compounds in these vegetables. These studies will help to obtain novel plant lines that will be able to accumulate higher levels of bioactive compounds, through conventional breeding programs, or, in alternative, through more efficient metabolic engineering approaches.

Acknowledgments: The authors would like to thank BenTen Project (POR Campania 2007/2013) for the financial support to their activities.

Author Contributions: A.R., G.P., D.M.M. and M.M.R wrote the manuscript with the contribution of other authors; A.B. and A.E. revised the manuscript.

Conflicts of Interest: The authors declare no conflict of interest. 


\section{References}

1. Sasaki, K.; Takahashi, T. A flavonoid from Brassica rapa flower as UV-absorbing nectar guide. Phytochemistry 2002, 61, 339-343. [CrossRef]

2. Jahangir, M.; Kim, H.K.; Choi, Y.H.; Verpoorte, R. Health-affecting compounds in Brassicaceae. Compr. Rev. Food Sci. Food Saf. 2009, 8, 31-43. [CrossRef]

3. Comhaire, F. Nutriceutical approach to the metabolic syndrome. Endocrinol. Metab. Syndr. 2014, 3, 134. [CrossRef]

4. De Pascale, S.; Maggio, A.; Pernice, R.; Fogliano, V.; Barbieri, G. Sulphur fertilization may improve the nutritional value of Brassica rapa L. subsp. sylvestris. Eur. J. Agron. 2007, 26, 418-424. [CrossRef]

5. Lippmann, D.; Lehmann, C.; Florian, S.; Barknowitz, G.; Haack, M.; Mewis, I.; Wiesner, M.; Schreiner, M.; Glatt, H.; Brigelius-Flohé, R. Glucosinolates from pakchoi and broccoli induce enzymes and inhibit inflammation and colon cancer differently. Food Funct. 2014, 5, 1073-1081. [CrossRef] [PubMed]

6. Wilson, R.A.; Sangha, M.H.; Banga, S.S.; Atwal, A.K.; Gupta, S. Heat stress tolerance in relation to oxidative stress and antioxidants in Brassica juncea. J. Environ. Biol. 2014, 35, 383-387. [PubMed]

7. Jeon, S.M.; Kim, J.E.; Shin, S.K.; Kwon, E.Y.; Jung, U.J.; Baek, N.I.; Lee, K.T.; Jeong, T.S.; Chung, H.G.; Choi, M.S. Randomized double-blind placebo-controlled trial of powdered Brassica rapa ethanol extract on alteration of body composition and plasma lipid and adipocytokine profiles in overweight subjects. J. Med. Food 2013, 16, 133-138. [CrossRef] [PubMed]

8. Shah, M.A.; Sarker, M.M.R.; Gousuddin, M. Antidiabetic potential of Brassica oleracea var. Italica in Type 2 diabetic Sprague dawley (sd) rats. Int. J. Phar. Phytochem. Res. 2016, 8, 462-469.

9. Peluso, I.; Palmery, M. Is a flavonoid-rich diet with steamer cooking safe during calcineurin inhibitors therapy? J. Clin. Pharm. Therap. 2014, 39, 471-474. [CrossRef] [PubMed]

10. Cohen, J.H.; Kristal, A.R.; Stanford, J.L. Fruit and vegetable intakes and prostate cancer risk. J. Nat. Cancer Inst. 2000, 92, 61-68. [CrossRef] [PubMed]

11. An, S.; Han, J.I.; Kim, M.J.; Park, J.S.; Han, J.M.; Baek, N.I.; Chung, H.G.; Choi, M.S.; Lee, K.T.; Jeong, T.S. Ethanolic extracts of Brassica campestris spp. rapa roots prevent high-fat diet-induced obesity via beta(3)-adrenergic regulation of white adipocyte lipolytic activity. J. Med. Food. 2010, 13, 406-414. [CrossRef] [PubMed]

12. Padayatty, S.J.; Katz, A.; Wang, Y.; Eck, P.; Kwon, O.; Lee, J.H.; Chen, S.; Corpe, C.; Dutta, A.; Dutta, S.K.; et al. Vitamin $\mathrm{C}$ as an antioxidant: Evaluation of its role in disease prevention. J. Am. Coll. Nutr. 2003, 22, 18-35. [CrossRef] [PubMed]

13. Rodríguez, J.A.; Nespereira, B.; Pérez-Ilzarbe, M.; Eguinoa, E.; Páramo, J.A. Vitamins C and E prevent endothelial VEGF and VEGFR-2 overexpression induced by porcine hypercholesterolemic LDL. Cardiovasc. Res. 2005, 65, 665-673. [CrossRef] [PubMed]

14. Gallo, M.; Esposito, G.; Ferracane, R.; Vinale, F.; Naviglio, D. Beneficial effects of Trichoderma genus microbes on qualitative parameters of Brassica rapa L. subsp. sylvestris L. Janch. var. esculenta Hort. Eur. Food Res. Technol. 2013, 236, 1063-1071. [CrossRef]

15. Podsędek, A. Natural antioxidants and antioxidant capacity of Brassica vegetables: A review. LWT Food Sci. Technol. 2007, 40,1-11. [CrossRef]

16. Rose, P.; Huang, Q.; Ong, C.N.; Whiteman, M. Broccoli and watercress suppress matrix metalloproteinase-9 activity and invasiveness of human MDA-MB-231 breast cancer cells. Toxicol. Appl. Pharmacol. 2005, 209, 105-113. [CrossRef] [PubMed]

17. Das, S.; Tyagi, A.K.; Kaur, H. Cancer modulation by glucosinolates: A review. Current Sci. 2000, 79, 1665-1671.

18. Yogeeta, S.K.; Hanumantra, R.B.R.; Gnanapragasam, A.; Senthilkumar, S.; Subhashini, R.; Devaki, T. Attenuation of abnormalities in the lipid metabolism during experimental myocardial infarction induced by isoproterenol in rats: beneficial effect of ferulic acid and ascorbic acid. Basic Clin. Pharmacol. Toxicol. 2006, 98, 467-472. [CrossRef] [PubMed]

19. Vallejo, F.; Tomas-Barberan, F.A.; Garcia-Viguera, C. Effect of climatic and sulphur fertilisation conditions, on phenolic compounds and vitamin C, in the inflorescences of eight broccoli cultivars. Eur. Food Res. Technol. 2003, 216, 395-401. [CrossRef] 
20. Kaur, C.; Kumar, K.; Anil, D.; Kapoor, H.C. Variations in antioxidant activity in broccoli (Brassica oleracea L.) cultivars. J. Food Biochem. 2007, 31, 621-638. [CrossRef]

21. Borowski, J.; Szajdek, A.; Borowska, E.J.; Ciska, E.; Zieliński, H. Content of selected bioactive components and antioxidant properties of broccoli (Brassica oleracea L.). Eur. Food Res. Technol. 2008, 226, 459-465. [CrossRef]

22. Koh, E.; Wimalasiri, K.M.S.; Chassy, A.W.; Mitchell, A.E. Content of ascorbic acid, quercetin, kaempferol and total phenolics in commercial broccoli. J. Food Compos. Anal. 2009, 22, 637-643. [CrossRef]

23. Domínguez-Perles, R.; Mena, P.; García-Viguera, C.; Moreno, D.A. Brassica foods as a dietary source of vitamin C: A review. Crit. Rev. Food Sci. Nutr. 2014, 54, 1076-1091. [CrossRef] [PubMed]

24. Herranz-López, M.; Fernández-Arroyo, S.; Pérez-Sanchez, A.; Barrajón-Catalána, E.; Beltrán-Debónc, R.; Menéndez, J.A.; Alonso-Villaverdee, C.; Segura-Carretero, A.; Jovenc, J.; Micol, V. Synergism of plant-derived polyphenols in adipogenesis. Perspimpl. Phyt. 2012, 19, 253-261. [CrossRef] [PubMed]

25. Zhang, B.; Kang, M.; Xie, Q.; Xu, B.; Sun, C.; Chen, K.; Wu, Y. Anthocyanins from Chinese bayberry extract protect beta cells from oxidative stress-mediated injury via HO-1 upregulation. J. Agric. Food Chem. 2011, 59, 537-545. [CrossRef] [PubMed]

26. Vessal, M.; Hemmati, M.; Vasei, M. Antidiabetic effects of quercetin in streptozocin-induced diabetic rats. Comp. Biochem. Physiol. Toxicol. Pharmacol. 2003, 135, 357-364. [CrossRef]

27. Tabatabaei-Malazy, O.; Larijani, B.; Abdollahi, M.A. Novel management of diabetes by means of strong antioxidants' combination. J. Med. Hypotheses Ideas 2013, 7, 25-30. [CrossRef]

28. Fard, M.H.; Naseh, G.; Lotfi, N.; Hosseini, S.M.; Hosseini, M. Effects of aqueous extract of turnip leaf (Brassica rapa) in alloxan-induced diabetic rats. Avicenna J. Phytomed. 2015, 5, 148-156.

29. Büchert, A.M.; Lobato, M.E.G.; Villarreal, N.M.; Civello, P.M.; Martínez, G.A. Effect of visible light treatments on postharvest senescence of broccoli (Brassica oleracea L.). J. Sci. Food Agric. 2011, 91, 355-361. [CrossRef] [PubMed]

30. Suzuki, K.; Ito, Y.; Inoue, T.; Hamajima, N. Inverse association of serum carotenoids with prevalence of metabolic syndrome among Japanese. Clin. Nutr. 2011, 30, 369-375. [CrossRef] [PubMed]

31. Barbieri, G.; Bottino, A.; Orsini, F.; De Pascale, S. Sulfur fertilization and light exposure during storage are critical determinants of the nutritional value of ready-to-eat friariello campano (Brassica rapa L. subsp. sylvestris). J. Agric. Food Chem. 2009, 89, 2261-2266. [CrossRef]

32. Padilla, G.; Cartea, M.E.; Velasco, P.; de Haro, A.; Ordás, A. Variation of glucosinolates in vegetable crops of Brassica rapa. Phytochemistry 2007, 68, 536-545. [CrossRef] [PubMed]

33. Mukherjee, S.; Gangopadhyay, H.; Das, D. Broccoli: A unique vegetable that protects mammalian hearts through the redox cycling of the thioredoxin superfamily. J. Agric. Food Chem. 2008, 56, 609-617. [CrossRef] [PubMed]

34. Sankhari, J.M.; Thounaojam, M.C.; Jadeja, R.N.; Devkar, R.V.; Ramachandran, A.V. Anthocyanin-rich red cabbage (Brassica oleracea L.) extract attenuates cardiac and hepatic oxidative stress in rats fed an atherogenic diet. J. Sci. Food Agric. 2012, 92, 1688-1693. [CrossRef] [PubMed]

35. Kural, B.V.; Küçük, N.; Yücesan, F.B.; Örem, A. Effects of kale (Brassica oleracea L. var. acephala DC) leaves extracts on the susceptibility of very low and low density lipoproteins to oxidation. Ind. J. Biochem. Biophys. 2011, 48, 361-364.

36. Washida, K.; Miyata, M.; Koyama, T.; Yazawa, K.; Nomoto, K. Suppressive effect of yamato-mana (Brassica rapa L. oleifera group) constituent 3-Butenyl glucosinolate (gluconapin) on postprandial hypertriglyceridemia in mice. Biosci. Biotechnol. Biochem. 2010, 74, 1286-1289. [CrossRef] [PubMed]

37. Geremias, R.; Pedrosa, R.C.; Locatelli, C.; De Favere, V.T.; CouryPedrosa, R.; Laranjeira, M.C.M. Lipid lowering activity of hydrosoluble chitosan and association with Aloe vera $\mathrm{L}$. and Brassica olearaceae $\mathrm{L}$. Phytother. Res. 2006, 20, 288-293. [CrossRef] [PubMed]

38. Mohamed, S. Functional foods against metabolic syndrome (obesity, diabetes, hypertension and dyslipidemia) and cardiovasular disease. Trends Food Sci. Technol. 2014, 35, 114-128. [CrossRef]

39. Thangam, R.; Suresh, V.; Rajkumar, M.; Vincent, J.D.; Gunasekaran, P.; Anbazhagan, C.; Kaver, K.; Kannan, S. Antioxidant and in vitro anticancer effect of 2-pyrrolidinone rich fraction of Brassica oleracea var. capitata through induction of apoptosis in human cancer cells. Phytother. Res. 2013, 27, 1664-1670. [CrossRef] [PubMed] 
40. Gómez-Galera, S.; Rojas, E.; Sudhakar, D.; Zhu, C.; Pelacho, A.M.; Capell, T.; Christou, P. Critical evaluation of strategies for mineral fortification of staple food crops. Transgenic Res. 2010, 19, 165-180. [CrossRef] [PubMed]

41. Naqvi, S.; Farré, G.; Sanahuja, G.; Capell, T.; Zhu, C.; Christou, P. When more is better: Multigene engineering in plants. Trends Plant Sci. 2010, 15, 49-56. [CrossRef] [PubMed]

42. Zhu, C.; Sanahuja, G.; Yuan, D.; Farré, G.; Arjó, G.; Berman, J.; Zorrilla-López, U.; Banakar, R.; Bai, C.; Pérez-Massot, E.; et al. Biofortification of plants with altered antioxidant content and composition: Genetic engineering strategies. Plant Biotechnol. J. 2013, 11, 129-141. [CrossRef] [PubMed]

43. Brown, A.F.; Yousef, G.G.; Chebrolu, K.K.; Byrd, R.W.; Everhart, K.W.; Thomas, A.; Reid, R.W.; Parkin, I.A.; Sharpe, A.G.; Oliver, R.; et al. High-density single nucleotide polymorphism (SNP) array mapping in Brassica oleracea: Identification of QTL associated with carotenoid variation in broccoli florets. Theor. Appl. Genet. 2014, 127, 2051-2064. [CrossRef] [PubMed]

44. Sotelo, T.; Soengas, P.; Velasco, P.; Rodríguez, V.M.; Cartea, M.E. Identification of metabolic QTLs and candidate genes for glucosinolate synthesis in Brassica oleracea leaves, seeds and flower buds. PLoS ONE 2014, 9, e91428. [CrossRef] [PubMed]

45. Rahikainen, M.; Trotta, A.; Alegre, S.; Pascual, J.; Vuorinen, K.; Overmyer, K.; Moffatt, B.; Ravanel, S.; Glawischnig, E.; Kangasjärvi, S. PP2A-B' $\gamma$ modulates foliar trans-methylation capacity and the formation of 4-methoxy-indol-3-yl-methyl glucosinolate in Arabidopsis leaves. Plant J. 2017, 89, 112-127. [CrossRef] [PubMed]

46. Velasco, P.; Rodríguez, V.M.; Francisco, M.; Cartea, M.E.; Soengas, P. Genetics and breeding of Brassica crops. In Glucosinolates; Mérillon, J.M., Ramawat, K.G., Eds.; Springer: Cham, Switzerland, 2016; pp. 1-26.

47. Zang, Y.X.; Kim, J.H.; Park, Y.D.; Kim, D.H.; Hong, S.B. Metabolic engineering of aliphatic glucosinolates in Chinese cabbage plants expressing Arabidopsis MAM1, CYP79F1, and CYP83A1. BMB Rep. 2008, 41, 472-478. [CrossRef] [PubMed]

48. Seo, M.S.; Jin, M.; Chun, J.H.; Kim, S.J.; Park, B.S.; Shon, S.H.; Kim, J.S. Functional analysis of three BrMYB28 transcription factors controlling the biosynthesis of glucosinolates in Brassica rapa. Plant Mol. Biol. 2016, 90, 503-516. [CrossRef] [PubMed]

49. Bulgakov, V.P.; Veremeichik, G.N.; Grigorchuk, V.P.; Rybin, V.G.; Shkryl, Y.N. The rolB gene activates secondary metabolism in Arabidopsis calli via selective activation of genes encoding MYB and bHLH transcription factors. Plant Physiol. Biochem. 2016, 102, 70-79. [CrossRef] [PubMed]

50. Raclaru, M.; Gruber, J.; Kumar, R.; Sadre, R.; Lühs, W.; Zarhloul, M.K.; Friedt, W.; Frentzen, M.; Weier, D. Increase of the tocochromanol content in transgenic Brassica napus seeds by overexpression of key enzymes involved in prenylquinone biosynthesis. Mol. Breed. 2006, 18, 93-107. [CrossRef]

51. Fujisawa, M.; Takita, E.; Harada, H.; Sakurai, N.; Suzuki, H.; Ohyama, K.; Shibata, D.; Misawa, N. Pathway engineering of Brassica napus seeds using multiple key enzyme genes involved in ketocarotenoid formation. J. Exp. Bot. 2009, 60, 1319-1332. [CrossRef] [PubMed]

52. Li, X.; Gao, M.J.; Pan, H.Y.; Cui, D.J.; Gruber, M.Y. Purple canola: Arabidopsis PAP1 increases antioxidants and phenolics in Brassica napus leaves. J. Agric. Food Chem. 2010, 58, 1639-1645. [CrossRef] [PubMed]

53. Chung, I.M.; Rekha, K.; Rajakumar, G.; Thiruvengadam, M. Production of glucosinolates, phenolic compounds and associated gene expression profiles of hairy root cultures in turnip (Brassica rapa ssp. rapa). 3 Biotech 2016, 6, 175. [CrossRef] [PubMed]

54. Zang, Y.X.; Lim, M.H.; Park, B.S.; Hong, S.B.; Kim, D.H. Metabolic engineering of indole glucosinolates in Chinese cabbage plants by expression of Arabidopsis CYP79B2, CYP79B3, and CYP83B1. Mol. Cells 2008, 30, 231-241.

55. Zang, Y.X.; Kim, H.U.; Kim, J.A.; Lim, M.H.; Jin, M.; Lee, S.C.; Kwon, S.J.; Lee, S.I.; Hong, J.K.; Park, T.H.; et al. Genome-wide identification of glucosinolate synthesis genes in Brassica rapa. FEBS J. 2009, 276, 3559-3574. [CrossRef] [PubMed]

56. Ramirez-Estrada, K.; Vidal-Limon, H.; Hidalgo, D.; Moyano, E.; Golenioswki, M.; Cusidó, R.M.; Palazon, J. Elicitation, an effective strategy for the biotechnological production of bioactive high-added value compounds in plant cell factories. Molecules 2016, 21, 182. [CrossRef] [PubMed]

57. Sánchez-Pujante, P.J.; Borja-Martínez, M.; Pedreño, M.Á.; Almagro, L. Biosynthesis and bioactivity of glucosinolates and their production in plant in vitro cultures. Planta 2017, 246, 19-32. [CrossRef] [PubMed] 
58. Vallejo, F.; Tomás-Barberán, F.A.; García-Viguera, C. Phenolic compound contents in edible parts of broccoli inflorescences after domestic cooking. J. Sci. Food Agric. 2003, 83, 1511-1516. [CrossRef]

59. Francisco, M.; Moreno, D.A.; Cartea, M.E.; Ferreres, F.; Garcia-Viguera, C.; Velasco, P. Simultaneous identification of glucosinolates and phenolic compounds in a representative collection of vegetable Brassica rapa. J. Chromatogr. A 2009, 1216, 6611-6619. [CrossRef] [PubMed]

60. Galgano, F.; Favati, F.; Caruso, M.; Pietrafesa, A.; Natella, S. The Influence of processing and preservation on the retention of health-promoting compounds in broccoli. J. Food Sci. 2007, 72, S130-S135. [CrossRef] [PubMed]

61. Munkaya, A.W.; Mankule, E.E.; Oey, I.; Loey, A.V.; Hendrikx, M. Thermal stability of L-Ascorbic Acid and ascorbic acid oxidase in broccoli (Brassica oleracea var. italica). J. Food Sci. 2010, 75, 336-340. [CrossRef] [PubMed]

62. Song, L.; Thornalley, P.J. Effect of storage, processing and cooking on glucosinolate content of Brassica vegetables. Food Chem. Toxicol. 2007, 45, 216-224. [CrossRef] [PubMed]

63. Yuan, G.; Sun, B.; Yuan, J.; Wang, Q. Effects of different cooking methods on health-promoting compounds of broccoli. J. Zhejiang Univ. Sci. B. 2009, 10, 580-588. [CrossRef] [PubMed]

64. Traka, M.; Mithen, R. Glucosinolates, isothiocyanates and human health. Phytochem. Rev. 2009, 8, $269-282$. [CrossRef]

65. Jia, C.G.; Xu, C.J.; Wei, J.; Yuan, J.; Yuan, G.F.; Wang, B.L.; Wang, Q.M. Effect of modified atmosphere packaging on visual quality and glucosinolates of broccoli florets. Food Chem. 2009, 114, 28-37. [CrossRef]

66. Dos Reis, L.C.R.; de Oliveira, V.R.; Hagen, M.E.K.; Jablonski, A.; Flores, S.H.; de Oliveira Rios, A. Carotenoids, flavonoids, chlorophylls, phenolic compounds and antioxidant activity in fresh and cooked broccoli (Brassica oleracea var. Avenger) and cauliflower (Brassica oleracea var. Alphina F1). LWT Food Sci. Technol. 2015, 63, 177-183. [CrossRef]

67. Francisco, M.; Tortosa, M.; del Carmen Martínez-Ballesta, M.; Velasco, P.; García-Viguera, C.; Moreno, D.A. Nutritional and phytochemical value of Brassica crops from the agri-food perspective. Ann. Appl. Biol. 2017, 170, 273-285. [CrossRef] 